\title{
Effect of Passivation on Properties and Performance of Perovskite Solar Cells
}

\author{
Radwa Esmael, ${ }^{1,}$, Hassanin El-Labany ${ }^{1}$, Shaker Ebrahim ${ }^{3}$, \\ Ayman El-Tahan ${ }^{i *}$
}

${ }^{1}$ Physics Department, Faculty of Science, Tanta University, P.O. Box: 44519, Tanta, Egypt.

${ }^{2}$ Higher Institute of Engineering and Technology, P.O. Box: 31739, Egypt.

${ }^{3}$ Department of Materials Science, Institute of Graduate Studies and

Research, Alexandria University, P.O. Box: 832, Alexandria, Egypt.

*Correspond other; ayman.eltahan@science.tanta.edu.eg

Perovskite solar cells (PSCs) represent one of the most models of the organic-inorganic solar cells which have achieved a great success in the last years. However, there are some of challenges facing this success such the barrier between the layers' interfaces and the presence of grains that impedes the passage of the charge carriers. Consequently, the aim of this work is to synthesize and characterize passivated peroviskte layers using different passivation techniques for producing treated perovskite solar cells. These treated layers were characterized by scanning electron microscope (SEM), UV-visible spectroscopy, photoluminescence, X-ray diffraction (XRD), Fourier transform infrared (FTIR) and current densityvoltage measurements. The optimal performance of the fabricated and passivated PSCs with a structure of FTO/blocking layer/mesoporous layer $/ \mathrm{TiCl}_{4} /$ methylamonium (MA)PbI ${ }_{3-x} \mathrm{Cl}_{x} /$ chlorobenzene/C had short circuit current density (JSC), open circuit voltage (Voc), fill factor (FF) and efficiency of $20 \mathrm{~mA} / \mathrm{cm}^{2}, 0.56 \mathrm{~V}, 0.29$ and $6.5 \%$, respectively.

\section{Introduction:}

The organic-inorganic lead halide perovskite solar cells (PSCs) are the most promising third generation solar cells. The power conversion efficiency (PCE) has exceeded 25\% [1].The optical and electrical advantages of the perovskite material such as low-cost, convenient fabrication techniques, largely tunable band gap (e.g., $\mathrm{CH}_{3} \mathrm{NH}_{3} \mathrm{PbX}_{3}$ has a band gap from $1.5 \mathrm{eV}$ to $2.3 \mathrm{eV}$ ) [2] and great light absorption coefficient (higher than $10^{4} \mathrm{~cm}^{-1}$ ) [3, 4]. However, there are several challenges facing the progress of this type of solar cells such as the weak contact between the interfacial layers, high series resistance between layers, large numbers of grain boundaries in the active layer and probable degradation of the organic layer. 
The passivation process refers to a material becoming passive or less corroded by the environment. Passivation involves the application of the outer layer of a shielding material as a microcoating and created by chemical reaction with the base material [5]. In the PSCs, the passivation taints to either chemical passivation, which reduces the defects trap states in order to optimize the charge transfer between various interfaces [6-10], or physical passivation, which isolates certain layers from the environment to avoid the degradation process. The self, surface and interface chemical passivation are commonly used and efficient strategies to reduce defects and improve the photovoltaic performance of PSCs [11-13].

The self-passivation was carried out by doping $\mathrm{MAPbI}_{3}$ with $\mathrm{Cl}$ and it was found that $10 \% \mathrm{PbCl}_{2}-\mathrm{MAPbI}_{3-\mathrm{x}} \mathrm{Cl}_{\mathrm{x}}$ film has a broadened bandgap which enables the sensibility to ultraviolet light to reduce defect density [14]. In addition, by applying the self-passivation method the efficiency of solar cell was increased from $1.63 \%$ (without passivation) to $4.09 \%$. The surface passivation technique on the active layer with a non-polar solvent was intended to reduce charge recombination and improve charge transport through the layer. This had led to smoother surface perovskite films with large grains. Moreover, the chlorobenzene washing process had produced compact, larger grain size, uniform and densely-packed crystalline surface topography [15-17].

In order to ensure crystallization of the perovskite layer, using chlorobenzene (CB) as an antisolvent solution, had resulted in planar perovskite films with highly homogenous and pinhole-free, and the efficiency had increased to be $4.45 \%$. The interface passivation method between the electron transport layer (ETL) and active layer was targeted to achieve the efficient electronselective contacts. PSCs consist of several layers between which the charges travel among themselves, and when each layer is connected the other; it resembles a series resistance increasing the charge recombination. To overcome on this resistance, a new ETL, which had made from $\mathrm{TiCl}_{4}$ was deposited on mesoporous $\mathrm{TiO}_{2}$ that had been fabricated by dipping method [18]. When performing different measurements, the cell with a new layer of $\mathrm{TiCl}_{4}$ treatment had a homogenous porosity surface suitable for perovskite infiltration, the recombination is reduced and the efficiency is increased to be $6.5 \%$ at the final of passivation series.

The objective of the presence work is to investigate the effect of different passivation techniques on the structural properties and performance of the fabricated PSCs. The hole free conventional mesoporous PSC is fabricated as a reference cell by an infiltration perovskite layer onto the carbon electrode. The PSCs are compared with and without passivation methods. The treated and passivated interfacial layers were characterized using scanning electron microscope (SEM), UV-visible spectroscopy, photoluminescence, X-ray 
diffraction (XRD), and Fourier transform infrared (FTIR) and current densityvoltage measurements.

\section{Materials and Methods:}

\subsection{Materials:}

Acetone (Sigma-Aldrich, 99\%), chlorobenzene (Fisher Scientific, 98\%), diethyl ether (Fisher Scientific, UK, 99\%), dimethyl sulfoxide (DMSO) (Across, New Jersey, USA, 99.8\%) have been purchased. Ethyl cellulose "EC" (HMW) (Sigma Aldrich, 48.0-49.5\% (w/w) ethoxyl basis), ethyl cellulose "EC" (LMW) (Sigma Aldrich, 48.0-49.5\% (w/w) ethoxyl basis), ethanolamine (Fluka, 99.5\%) have been purchased too. Fluorine doped Tin Oxide "FTO" glass substrate

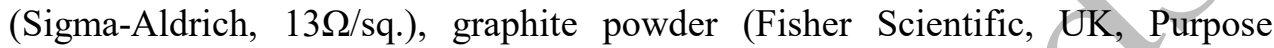
Grade), hydroiodic acid, 57wt\% (Across, New Jersey, USA) and isopropanol (Sigma-Aldrich, 99\%) have been purchased. Lead (II) chloride (Fisher Scientific, 99\%), lead (II) iodide (Fisher Scientific, 99\%), methylamine $\left(\mathrm{CH}_{3} \mathrm{NH}_{2}\right)$, extra pure and $40 \mathrm{wt} \%$ solution in water (Across, New Jersey, USA) has been bought. Titanium isopropoxide (Sigma Aldrich, 97\%), titanium tetrachloride "TiCl4" (Sigma Aldrich, 99\%), alpha-terpineol 97\% were as purchased from Across Organics. Acetyl acetone, $98 \%$ was obtained from Alpha Chemika and carbon black was received from carbon black Company (Alexandria, Egypt).

\subsection{Preparation of $\mathrm{TiO}_{2}$ blocking layer and $\mathrm{TiO}_{2}$ paste}

Ti isopropoxide $(0.6 \mathrm{ml})$ and acetylactone $(0.4 \mathrm{~mL})$ were mixed and stirred for $30 \mathrm{~min}$ at room temperature and then this mixture was added to $9 \mathrm{~mL}$ absolute ethanol and stirred for $30 \mathrm{~min}$ at room temperature. An amount of $58.6 \mathrm{~g}(0.2$ moles) of Ti isopropoxide was dissolved at once to $12 \mathrm{~g}$ ( 0.2 moles) of acetic acid and stirred at room temperature for 15 minute. Then, the precursor solution was poured into $290 \mathrm{~mL}$ water quickly while stirring at speed of $700 \mathrm{rpm}$. After $1 \mathrm{hr}$ of stirring, $4 \mathrm{~mL}$ of nitric acid was added to the mixture and then heated $80^{\circ} \mathrm{C}$ in 40 minute and peptized for $75 \mathrm{~min}$ with adding the water to this solution until the final volume becomes $370 \mathrm{~mL}$. The mixture solution was then kept in autoclave at $250^{\circ} \mathrm{C}$ for 12 hours. After this step, $2.4 \mathrm{~mL}$ of $65 \%$ nitric acid was added and the dispersed solution was sonicated [19-22]. The mixture was then concentrated by using rotary evaporator and to get the concentrated mixture from this solution, the organic and other solvents were removed by centrifuge and this step was repeated three times, then we dividing this mixture in many tubes and washing with ethanol many times a white precipitate containing $40 \mathrm{wt} . \% \mathrm{TiO}_{2}$ in ethanol was obtained. Finally, $\mathrm{TiO}_{2}$ was dried in a vacuum oven for 6 hours at $80^{\circ} \mathrm{C}$ and then $\mathrm{TiO}_{2}$ was grinded using a mortar to produce a fine white powder.

There were two kinds of Ethyl Cellulose (EC) powders used in this study to prepare $\mathrm{TiO}_{2}$ paste from EC (5-15 mPa.s) and EC (30-50 mPa.s). $45 \mathrm{~g}$ of the EC (5-15 mPa.s) and $35 \mathrm{~g}$ of the EC (30-50 mPa.s) Ethyl Cellulose powder were dissolved in ethanol to have $10 \mathrm{wt} . \%$ solution. $16 \mathrm{~g}$ of the prepared $\mathrm{TiO}_{2}$ and 64.9 
$\mathrm{g}$ of alpha-terpineol were added to the ethanolic EC solution and diluted with 80 $\mathrm{mL}$ of ethanol to obtain a total volume of $280 \mathrm{~mL}$. The mixture was then sonicated and stirred. Water and ethanol were removed from $\mathrm{TiO}_{2}$ and e EC solution by rotary evaporator from initial temperature of $40^{\circ} \mathrm{C}$ to a final temperature at $50^{\circ} \mathrm{C}$. The final paste was made with a hand mill. The final paste containing $18 \mathrm{wt} . \% \mathrm{TiO}_{2}, 9 \mathrm{wt} . \% \mathrm{EC}$ and $73 \mathrm{wt} . \%$ terpineol was used for both characterizations and devices fabrication. $0.04 \mathrm{~mL}$ of $99 \% \mathrm{TiCl}_{4}$ solution was prepared by slowly droppingTiCl $\mathrm{O}_{4}$ over $50 \mathrm{~g}$ DI in ice and then diluted with 250 $\mathrm{mL}$ DI water in a $300 \mathrm{~mL}$ at room temperature.

\subsection{Synthesis of MAI, MAPbI $I_{3}$ and $M A P b I_{3-x} C_{x}$}

Both of $20 \mathrm{~mL}$ of methylamine and $30 \mathrm{~mL}$ of $\mathrm{HI}$ were mixed and stirred for two hours at $0^{\circ} \mathrm{C}$. Red color precipitates were recovered by solvent evaporation using rotary evaporator at $60{ }^{\circ} \mathrm{C}$. This precipitate was rinsed with diethyl ether until the red color of the precipitate changed from red to yellow to colorless and then recrystallized in ethanol. The white crystalline powder of Methyleamonium Iodide (MAI) was dried in a vacuum oven at $60^{\circ} \mathrm{C}$ for 24 hours [23-27]. $\mathrm{MAPbI}_{3}$ perovskite precursor solution was prepared in a nitrogen filled glovebox by dissolving $461 \mathrm{mg}$ of $\mathrm{PbI}_{2}, 159 \mathrm{mg}$ of MAI, $0.5 \mathrm{~mL}$ of DMSO and $0.5 \mathrm{~mL}$ of Daymethyle formamide (DMF) under/stirring overnight. $\mathrm{MAPbI}_{3-\mathrm{x}} \mathrm{Cl}_{\mathrm{x}}$ perovskite precursor solution was prepared by dissolving $461 \mathrm{mg}$ of $\mathrm{PbI}_{2}, 159 \mathrm{mg}$ of MAI, 35 $\mathrm{mg}$ of $\mathrm{PbCl}_{2}(10 \mathrm{wt} \%), 0.5 \mathrm{~mL}$ of DMSO and $0.5 \mathrm{~mL}$ of DMF under stirring overnight. The prepared $\mathrm{MAPbI}_{3-\mathrm{x}} \mathrm{Cl}_{\mathrm{x}}$ perovskite solution was filtered by using a syringe filter prior to be used for the deposition of films.

\subsection{Characterization techniques}

The optical properties of the prepared perovskite and different layers were obtained by UV-visible spectroscopy (spectrophotometer, Thermo Scientific 600, USA). X-ray diffraction of GO was obtained using (X-ray 7000 Shimadzu, Japan). Photoluminescence spectra were recorded for the perovskite layer deposited on a glass and on the prepared HTLs at an excitation wavelength of 420 nm using (spectrophotometry Perkin Elmer L55, USA).The surface of different films was investigated using scanning electron microscopy (SEM "JEOL JSM6360 LA", Japan) to study the morphology and the homogeneity of the surface. The structural identifications were confirmed by the FTIR spectroscopy using Fourier transform infrared spectrophotometer (Spectrum BX 11- LX 18-5255 Perkin Elmer). The spectra were recorded in the wavenumber range of 400-4000 $\mathrm{cm}^{-1}$. To obtain the FTIR spectra the powder from each layer was grinded with $\mathrm{KBr}$ powder. The J-V curves of the fabricated solar cells were measured using Metrohm Auto lab potentio state attached with calibrated halogen lamp with an intensity power of $80 \mathrm{~mW} / \mathrm{cm}^{2}$. 


\subsection{PSCs fabrication}

The cleaning steps were carefully carried out these steps included sonication of the substrates in various solvents starting from acetone for 5 to 10 minutes, then Isopropanole (IPA) for 10 minutes and acetone again for 10 minutes. The FTO substrates were immediately rinsed by flow of nitrogen to dry and avoid adhesion of impurities on the wet surfaces.

The cell without passivation consists of $\mathrm{FTO} / \mathrm{BL}-\mathrm{TiO}_{2} / \mathrm{MP}-$ $\mathrm{TiO}_{2} / \mathrm{MAPb}_{3} / \mathrm{CCE}$ heterostrucutre as indicated in Fig.1. On top of the cleaned substrates the $\mathrm{TiO}_{2}$ compact layer was deposited at $2000 \mathrm{rpm}$ spincoating speed for 30 second and anealed at $450{ }^{\circ} \mathrm{C}$ for 30 minutes. Afterthat, the $\mathrm{TiO}_{2}$ mesoporous layer was deposited on the top of the blocking layer at $4000 \mathrm{rpm}$ for $30 \mathrm{~s}$ and anealed again at $450{ }^{\circ} \mathrm{C}$ for $30 \mathrm{~min}$. After cooling to room temperature a mesoscopic CCE was deposited by doctor blade method and anealed at $450{ }^{\circ} \mathrm{C}$ for $30 \mathrm{~min}$ [28-29]. Finally a $30 \mu \mathrm{l}$ of $\mathrm{MAPbI}_{3}$ precurcer was deposited and infiltrated through the mesoscopic carbon layer at $2000 \mathrm{rpm}$ for $30 \mathrm{~s}$ and followed by drying at $100^{\circ} \mathrm{C}$ for $30 \mathrm{~min}$ on a hot plate.

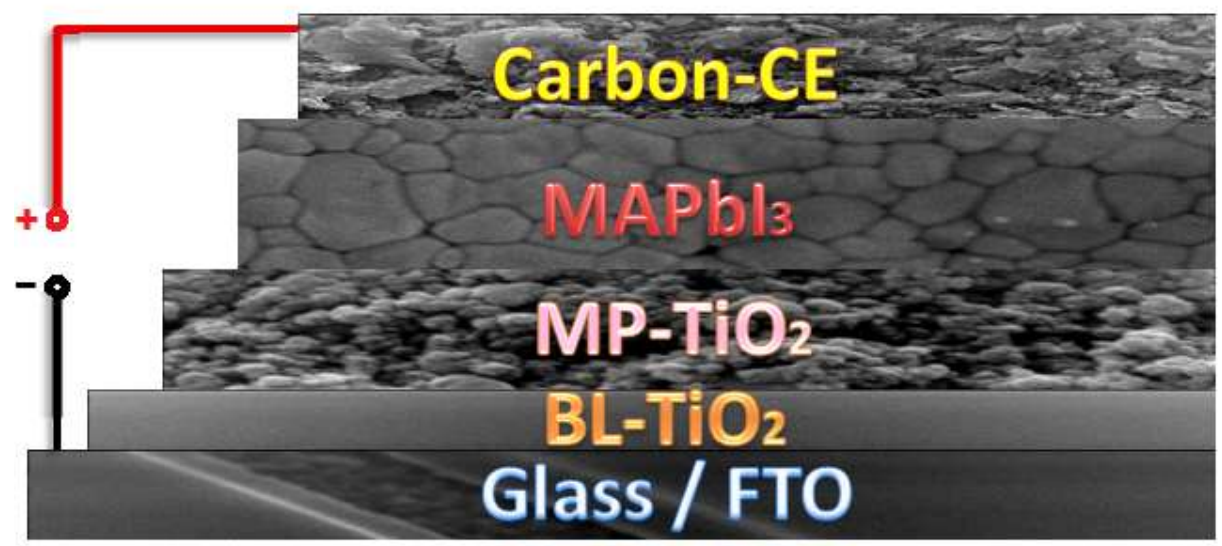

Fig. (1): Schematic diagram of the fabricated PSCs based on the mesoporous configuration of $\mathrm{FTO} / \mathrm{BL}-\mathrm{TiO}_{2} / \mathrm{MP}-\mathrm{TiO}_{2} /$ Active layer/CCE.

The PSCs with a self passivation(FTO/BL-TiO $2 / \mathrm{MP}-\mathrm{TiO}_{2} / \mathrm{MAPbI}_{3-}$ $\left.{ }_{\mathrm{x}} \mathrm{Cl}_{\mathrm{x}} / \mathrm{CCE}\right)$ structure was fabricated. The third type of cell was based on (FTO/BL$\left.\mathrm{TiO}_{2} / \mathrm{mP}^{-\mathrm{TiO}_{2}} / \mathrm{MAPbI}_{3-\mathrm{x}} \mathrm{Cl}_{\mathrm{x}} / \mathrm{CB} / \mathrm{CCE}\right)$ to study the effect of surface passivation. To have higher performance with adding $\mathrm{CB}$ as the antisolvent solution very quickly during spincoating process on the last active layer [30].The fourth fabricated PSC has the three types of passivation and involvesFTO/BL/TiO $/ 2 / \mathrm{MP}-$ $\mathrm{TiO}_{2} / \mathrm{TiCl}_{4} / \mathrm{MAPbI}_{3-\mathrm{x}} \mathrm{Cl}_{\mathrm{x}} / \mathrm{CB} / \mathrm{CCE}$ structure to study the effect of interface passivation. In this cell the dense and mesoporous $\mathrm{TiO}_{2}$ was deposited as previously mentionedand when the substrate with the $\mathrm{TiO}_{2}$ films was treated in $0.04 \mathrm{M} \mathrm{TiCl}_{4}$ solution at $70^{\circ} \mathrm{C}$ for $10 \mathrm{~min}$, followed 


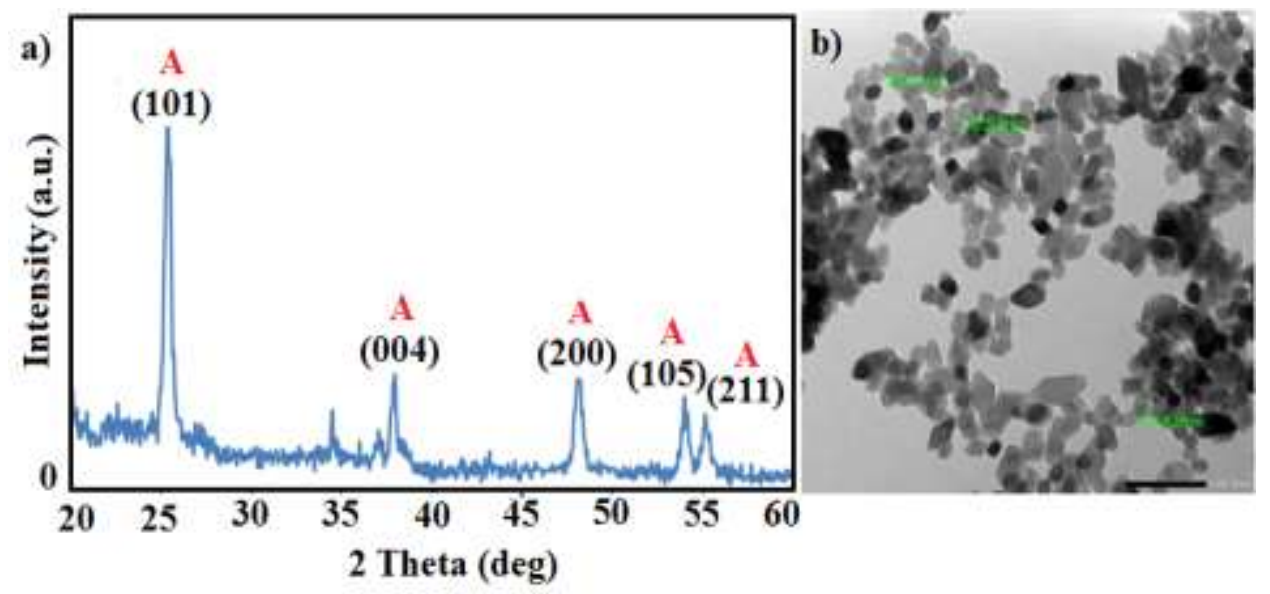

Fig. (2): (a) XRD pattern for $\mathrm{TiO}_{2}$ nanoparticles films prepared on glass/FTO substrate and (b) TEM micrographs of the pattern of $\mathrm{TiO}_{2}$ nanoparticles.

by rinsing with DI-water and ethanol and dried at $100^{\circ} \mathrm{C}$ for $10 \mathrm{~min}$. Then, the $\mathrm{TiO}_{2}$ film was annealed again at $500{ }^{\circ} \mathrm{C}$ for $30 \mathrm{~min}$ before the deposition of the perovskite layer [31, 32].CCE paste was synthesized by mixing $2 \mathrm{~g}$ of carbon black powder with $6 \mathrm{~g}$ of graphite powders in $30 \mathrm{~mL} \alpha$-terpineol solution, and then $1 \mathrm{~g}$ of $\mathrm{ZrO}_{2}$ powder and $1 \mathrm{~g}$ of EC were diluted with $37.5 \mathrm{~mL}$ of ethanol to obtain homogenous solution and followed by stirring for 2 hours.

\section{Results and Discussion}

\subsection{Structure and morphology of $\mathrm{TiO}_{2}$ nanoparticles}

At the first, the $\mathrm{TiO}_{2}$ nanoparticles were characterized by using XRD pattern as displayed in Fig. (2.a). The diffraction peaks are used at $\left(2 \Theta=25.3^{\circ}\right.$, $37.9^{\mathrm{O}}, 48.1^{\mathrm{O}}, 54.8^{\mathrm{O}}$, and $\left.55.1^{\mathrm{O}}\right)$ corresponding to (lll $\left.\begin{array}{lll}1 & 0 & 1\end{array}\right),\left(\begin{array}{lll}0 & 0 & 4\end{array}\right),\left(\begin{array}{lll}2 & 0 & 0\end{array}\right),\left(\begin{array}{lll}1 & 0 & 5\end{array}\right)$, and

(2 1 1 1) planes of anatase, respectively [33, 34].There were no other detectable peaks corresponding to the rutile crystal structure. This confirms that the $\mathrm{TiO}_{2}$ nanoparticles are in the pure anatase crystal structure. In Fig. (2.b) the TEM micrograph shows that the average size of the nanoparticles is less than $30 \mathrm{~nm}$ and that the nanoparticles appeared to be relatively homogeneous and uniform in size albeit fairly agglomerated.

\subsection{Optical property of passivated perovskite films}

To understand the optical absorbance of $\mathrm{MAPbI}_{3}$ film and the effect of $\mathrm{Cl}$ element on the absorbance of $\mathrm{MAPbI}_{3-\mathrm{x}} \mathrm{Cl}_{\mathrm{x}}$ film, UV-Vis absorption is measured in the $300-850 \mathrm{~nm}$. The absorption edge for $\mathrm{MAPbI}_{3-\mathrm{x}} \mathrm{Cl}_{\mathrm{x}}$ film at approximately $750 \mathrm{~nm}$ is observed and a slight green shift compared with $748 \mathrm{~nm}$ for $\mathrm{MAPbI}_{3}$ film as shown in Fig. 3.a. The high absorbance of the perovskite film in the UV- 
visible range showed that the film was excellent capability of wide spectrum response. To explore the change in the optical band gap, the energy band $\left(E_{g}\right)$ was calculated according to Tauc's plot. The Tauc's plot shows that the $\mathrm{E}_{\mathrm{g}}$ of $\mathrm{MAPbI}_{3}$ film is approximately $1.45 \mathrm{eV}$ compared with $\mathrm{MAPbI}_{3-\mathrm{x}} \mathrm{Cl}_{\mathrm{x}}$ that showing $1.49 \mathrm{eV}$ as depicted in inset of Fig. (3a) [14].

The antisolvent treatment can be control the morphology of the PSC filmsand influence on structural and optical properties for $\mathrm{MAPbI}_{3-\mathrm{x}} \mathrm{Cl}_{\mathrm{x}} \mathrm{PSC}$ films. To understand the role of $\mathrm{CB}$ as an antisolvent onto the deposited $\mathrm{MAPbI}_{3-}$ ${ }_{\mathrm{x}} \mathrm{Cl}_{\mathrm{x}}$ film by comparing the absorption spectra of $\mathrm{MAPbI}_{3-\mathrm{x}} \mathrm{Cl}_{\mathrm{x}}$ and the new composite $\mathrm{MAPbI}_{3-\mathrm{x}} \mathrm{Cl}_{\mathrm{x}}$ PSC films with non-polar solvent treatment as shown in Fig. 3.b. A slight red shift to $758 \mathrm{~nm}$ of $\mathrm{MAPbI}_{3-\mathrm{x}} \mathrm{Cl}_{\mathrm{x}}+\mathrm{CB}$ film is observed.

The high absorbance of the perovskite film in the UV-visible range enables the film with the excellent capability of wide spectrum response. To explore the change in the optical band gap, we calculate the energy band $\left(\mathrm{E}_{\mathrm{g}}\right)$ according to the reflection and transmission through the Tauc's plots. In inset of Fig. 3.b the Tauc plot shows that the Eg of $\mathrm{MAPbI}_{3-\mathrm{x}} \mathrm{Cl}_{\mathrm{x}}$ film is approximately $1.49 \mathrm{eV}$ compared with the passivated $\mathrm{MAPbI}_{3-\mathrm{x}} \mathrm{Cl}_{\mathrm{x}}$ with $\mathrm{CB}$ and showing $1.54 \mathrm{eV}$. The results demonstrate the enhancement of photoelectric performance of the passivated $\mathrm{MAPbI}_{3-\mathrm{x}} \mathrm{Cl}_{\mathrm{x}}$ with $\mathrm{CB}$ film in the ultraviolet spectrum because the adding of $\mathrm{CB}$ inMAPbI ${ }_{3-\mathrm{x}} \mathrm{Cl}_{\mathrm{x}}$ makes the cell surface more homogenous and pin hole free and enhance the absorbed incident light.
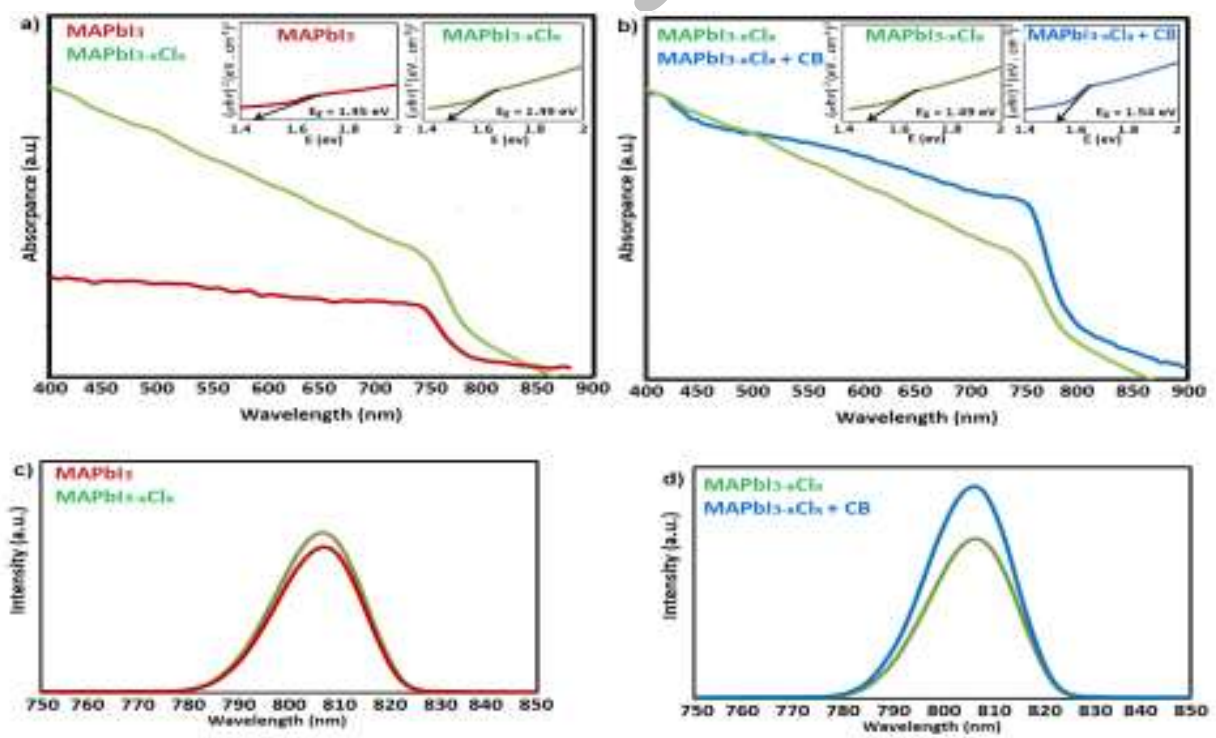

Fig. 3: a) Optical absorption spectra for the $\mathrm{MAPbI}_{3}$ and $\mathrm{MAPbI}_{3-\mathrm{x}} \mathrm{Cl}_{\mathrm{x}}$ thin film, a) inset $(\alpha h v)^{2}$ vs. hu curves for $\mathrm{MAPbI}_{3}$ and $\mathrm{MAPbI}_{3-\mathrm{x}} \mathrm{Cl}_{\mathrm{x}}$ thin films, b) Optical absorption spectra for the $\mathrm{MAPbI}_{3-\mathrm{x}} \mathrm{Cl}_{\mathrm{x}}$ and $\mathrm{MAPbI}_{3-\mathrm{x}} \mathrm{Cl}_{\mathrm{x}}+\mathrm{CB}$ thin film, $\mathrm{b}$ ) 
inset $(\alpha h v)^{2} v s$. hu curves for $\mathrm{MAPbI}_{3-\mathrm{x}} \mathrm{Cl}_{\mathrm{x}}$ and $\mathrm{MAPbI}_{3-\mathrm{x}} \mathrm{Cl}_{\mathrm{x}}+\mathrm{CB}$ thin films, c) PL spectra of the $\mathrm{MAPbI}_{3}$ and $\mathrm{MAPbI}_{3-\mathrm{x}} \mathrm{Cl}_{\mathrm{x}}$ thin films and d) PL spectra of $\mathrm{MAPbI}_{3-\mathrm{x}} \mathrm{Cl}_{\mathrm{x}}$ without $\mathrm{CB}$ treatment and $\mathrm{MAPbI}_{3-\mathrm{x}} \mathrm{Cl}_{\mathrm{x}}$ treated with $\mathrm{CB}$ thin films

Since the gap energy of the passivated $\mathrm{MAPbI}_{3-\mathrm{x}} \mathrm{Cl}_{\mathrm{x}}$ with $\mathrm{CB}$ film is greater, this means that the probability of charge recombination is less. It is concluded that the active layer of $\mathrm{MAPbI}_{3-\mathrm{x}} \mathrm{Cl}_{\mathrm{x}}$ passivated with $\mathrm{CB}$ overcomes the problem of charge recombination. The results demonstrate the enhancement of photoelectric performance of the $\mathrm{MAPbI}_{3-\mathrm{x}} \mathrm{Cl}_{\mathrm{x}}$ film in the ultraviolet spectrum because the doping of $\mathrm{Cl}$ in $\mathrm{MAPbI}_{3}$ reduces the lattice symmetry and thus increases the material band gap. Since the gap energy of $\mathrm{MAPbI}_{3-\mathrm{x}} \mathrm{Cl}_{\mathrm{x}}$ film is greater, the probability of charge recombination is less.

The variations of Photoluminance (PL) intensity with wavelength for $\mathrm{MAPbI}_{3}$ and $\mathrm{MAPbI}_{3-\mathrm{x}} \mathrm{Cl}_{\mathrm{x}}$ are presented in Fig. 3c. The PL spectra show a slight green-shift with chloride incorporation, which is consistent with previous report. Compared to the $\mathrm{MAPbI}_{3}$, the green-shift in the mixed peroyskite of $\mathrm{MAPbI}_{3-\mathrm{x}} \mathrm{Cl}_{\mathrm{x}}$ may be related to incorporation of chloride into the $\mathrm{MAPbI}_{3}$ crystal lattice, which reduces the lattice symmetry and thus increases the material band gap [27]. The excitation intensity controls the density of photoexcited electrons and holes, which governs the behavior of these carriers. Each electron-hole recombination mechanism has a distinct functional dependence on carrier density. The $\mathrm{MAPbI}_{3}$ layer shows lower PL peak intensity, indicating the lower excitation and higher recombination rate. It confirms that the mixing by $\mathrm{Cl}$ produces more excitation and reduces the charge recombination at the interfaces [35]. When the $\mathrm{MAPbI}_{3-}$ ${ }_{x} \mathrm{Cl}_{\mathrm{x}}$ thin layer was treated by CB, the PL spectrum is shown in Fig. 3. d. The $\mathrm{MAPbI}_{3-\mathrm{x}} \mathrm{Cl}_{\mathrm{x}}$ film without $\mathrm{CB}$ treatment has a lower PL peak intensity, indicating the lower excitation and higher recombination rate than those appearing when the $\mathrm{MAPbI}_{3-\mathrm{x}} \mathrm{Cl}_{\mathrm{x}}$ thin layer was treated by CB.The PSCs films have totally different surface morphologies with and without the non-polar solvent treatment in the previous studies [36-38]. The PSC film without the CB washing had very poor surface coverage, which can cause decrease in the absorption property compared with fully covered film.

To improve the properties of final cell, another layer the electron transport layer $\left(\mathrm{MP}-\mathrm{TiO}_{2}\right)$ is inserted. In order to make sure that the charge does not overlap again throughout the cell, the charge transfer layer must be treated because of its large gaps, and this treatment is made by depositing a very small thickness layer of the diluted $\mathrm{TiCl}_{4}$ solution.To gain insight into the influence of $\mathrm{TiCl}_{4}$ treatment on the optical properties of $\mathrm{TiO}_{2}$, we performed a transmittance measurement. The quality of perovskite films directly affects the device performance of PSCs; therefore, to investigate the effect of post-treatment of $\mathrm{TiO}_{2}$ on the deposition of the perovskite film, we deposited perovskite thin films on top of the $\mathrm{TiO}_{2}$ films with $\mathrm{TiCl}_{4}$ treatment. UV-V light transmission was measured in 
the $300-900 \mathrm{~nm}$ range by a UV-visible spectrophotometer. As depicted in Fig.(4) after treated with $\mathrm{TiCl}_{4}$, the transmittances of $\mathrm{TiO}_{2}$ substrates were slightly lower than the control sample.

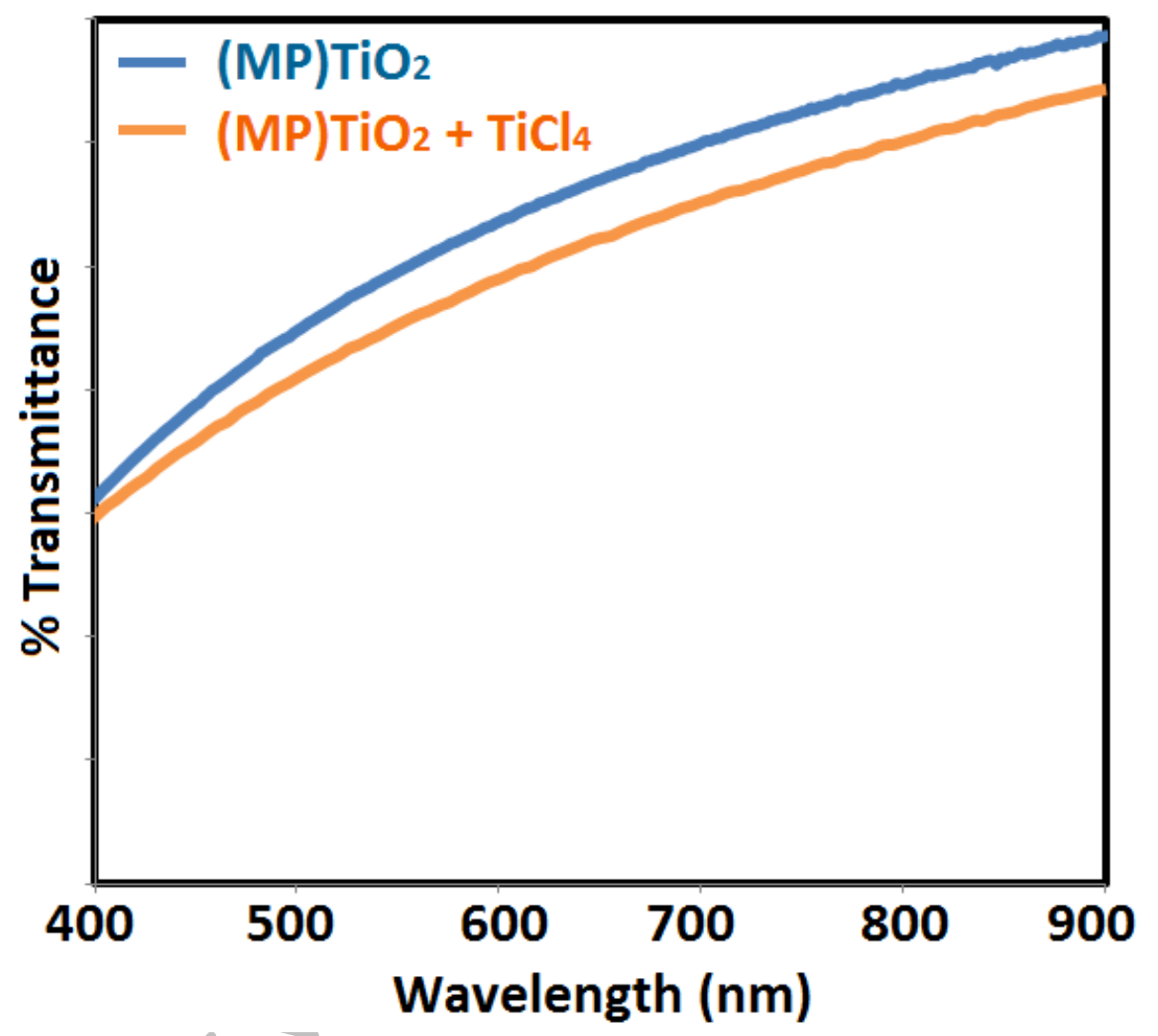

Fig. (4): UV-Vis absorption curves of the $\mathrm{M}-\mathrm{TiO}_{2}$ and $\mathrm{M}-\mathrm{TiO}_{2}+\mathrm{TiCl}_{4}$ thin film.

3.3. Structural, crystalline and morphological properties of passivated perovskite films. 
To gain insight into the effects of the $\mathrm{PbCl}_{2}$ additive on the crystal structure of the perovskite material, XRD data collected for the diffraction patterns of the films are represented in Fig. 5 (a, b). From the data of Fig. (5.b), it is noted that no peak from $\mathrm{PbCl}_{2}$ is observed in the XRD patterns indicating that the added $\mathrm{PbCl}_{2}$ is completely consumed in the reaction with MAI to either form $\mathrm{PbI}_{2}$ or $\mathrm{MAPbCl}_{3}$. The existence of $\mathrm{PbI}_{2}$ in $10 \% \mathrm{PbCl}_{2}-\mathrm{MAPbI}_{3-\mathrm{x}} \mathrm{Cl}_{\mathrm{x}}$ film is attributed to the reaction of MAI with $\mathrm{PbCl}_{2}$ rather than $\mathrm{PbI}_{2}$. As a result, there is insufficient MAI to react with $\mathrm{PbI}_{2}$, leading to the residues of $\mathrm{PbI}_{2}$ in perovskite film [14]. Yu et al. [39] reported that the several reaction processes are involved in the formation of a film by these mixed solutions, and $\mathrm{Cl}$ elements slow down the formation of $\mathrm{MAPbI}_{3-\mathrm{x}} \mathrm{Cl}_{\mathrm{x}}$ crystal. Meanwhile, the excess of $\mathrm{PbI}_{2}$ in the perovskite film at grain boundaries is beneficial because it forms an energy barrier that hinders leakage of both electrons and the holes from active layer for recombination [40].
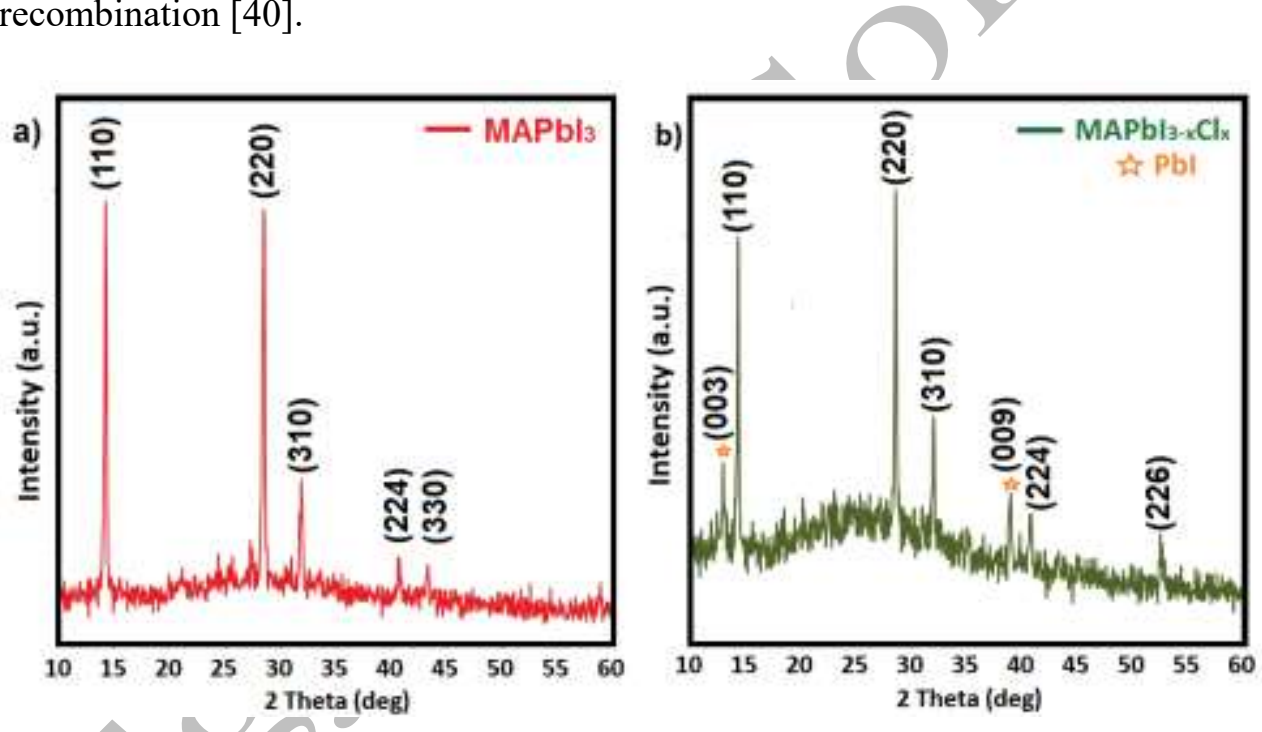

Figure (5) XRD patterns of a)MAPbI 3 and b) MAPbI 3-x Cl $x$ thin film.

By comparing the XRD patterns, it is found that the presence of peaks at $14.2^{\circ}(110), 28.5^{\circ}(220), 31.9^{\circ}(310), 40.55^{\circ}(224)$ and $43.25^{\circ}(330)$ indicates the successful formation of $\mathrm{MAPbI}_{3}[41]$. The results show that the (110) and (220) peaks are very strong compared to the other peaks, demonstrating better crystallization of perovskite film in these directions which is preferred for photovoltaic performance [42]. 
As shown in Fig. (5a and 5b) these peaks are shifted to $14.25^{\circ}(110), 28.5^{\circ}$ (220), $31.95^{\circ}(310), 40.74^{\circ}(224)$ and $52.45^{\circ}$ (226) for the $\mathrm{MAPbI}_{3-\mathrm{x}} \mathrm{Cl}_{\mathrm{x}}$ [43]. This shift is slightly larger due to the inclusion of $\mathrm{Cl}$ ion into the crystal lattice of $\mathrm{MAPbI}_{3}$. The appearance of series of new diffraction peaks are in good agreement with literature on the tetragonal phase of the perovskite [44]. Furthermore, the figure shows that same $\mathrm{Pbl}_{2}$ in the $\mathrm{MAPbI}_{3-\mathrm{x}} \mathrm{Cl}_{\mathrm{x}}$ precursor appears at $12.9^{\circ}(003)$ and $38.9^{\circ}(009)$ and this unreacted $\mathrm{PbI}_{2}$ passivates grain boundaries which generally worked as recombination centers.

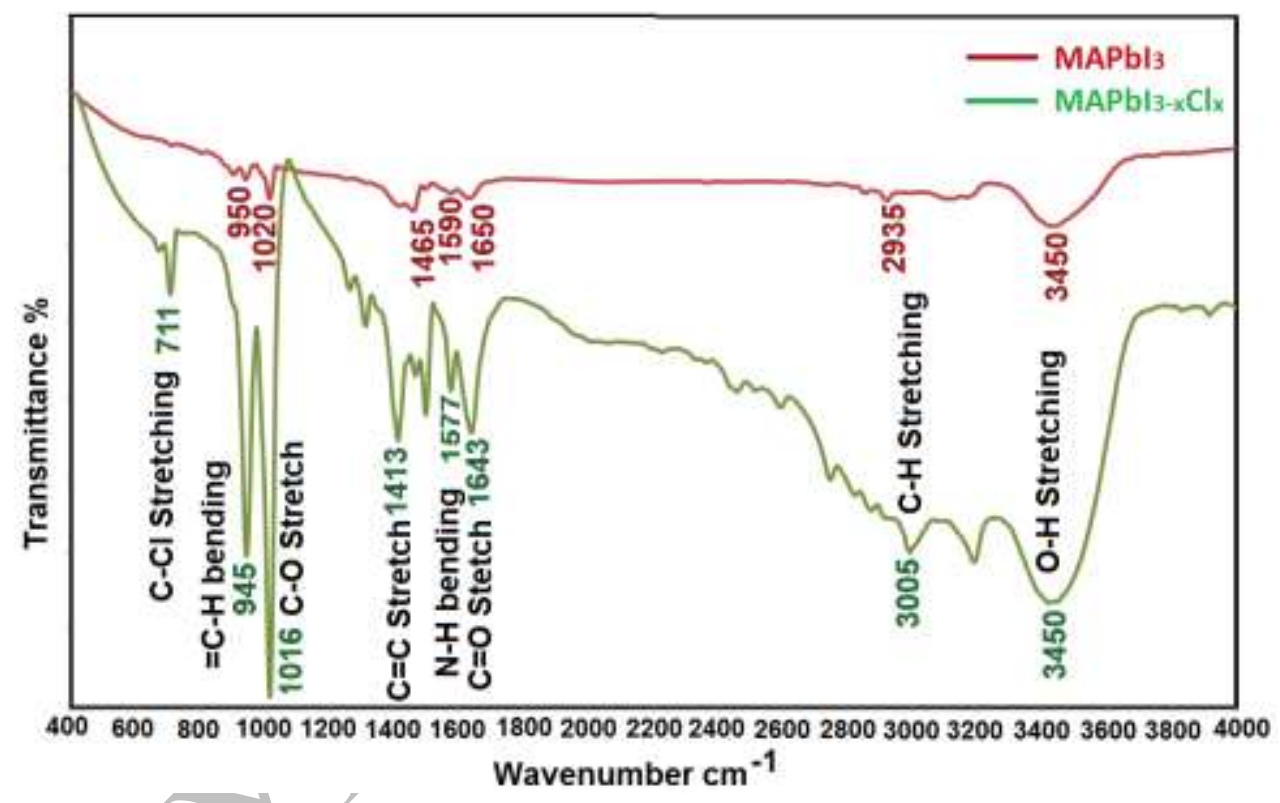

Figure (6)FTIR spectra of the MAPbI 3 and MAPbI 3-x Cl x thin film.

The chemical structures of $\mathrm{CH}_{3} \mathrm{NH}_{3} \mathrm{PbI}_{3}$ and $\mathrm{CH}_{3} \mathrm{NH}_{3} \mathrm{PbI}_{3-\mathrm{X}} \mathrm{Cl}_{\mathrm{X}}$ thin layer were characterized by using FTIR and the spectra are shown in Fig.6. The spectra show that the characteristic peaks are slightly different from the other two types of perovskite materials. The wide band around $3450 \mathrm{~cm}^{-1}$ in the two structures is due to the hydroxyl radical $\mathrm{O}-\mathrm{H}$ stretching (due to the decomposition process of perovskites), the peaks of $2935 \mathrm{~cm}^{-1}$ of $\mathrm{CH}_{3} \mathrm{NH}_{3} \mathrm{PbI}_{3}$ and $3005 \mathrm{~cm}^{-1}$ of $\mathrm{CH}_{3} \mathrm{NH}_{3} \mathrm{PbI}_{3-\mathrm{X}} \mathrm{Cl}_{\mathrm{X}}$ is of the $\mathrm{C}-\mathrm{H}$ stretch, the peaks appeared at $1643 \mathrm{~cm}^{-1}$ for $\mathrm{MAPbI}_{3-\mathrm{X}} \mathrm{Cl}_{\mathrm{X}}$ was shifted to $1650 \mathrm{~cm}^{-1}$ for $\mathrm{MAPbI}_{3}$ as it is expected that the $\mathrm{C}=\mathrm{O}$ bond strength in the $\mathrm{PbI}_{2}-\mathrm{MAI}-\mathrm{DMF}$ and $\mathrm{PbCl}_{2}$-MAI-DMF complex should be decreased due to the interaction with the Lewis acids $\mathrm{MA}^{+}, \mathrm{Pb}^{2+}$ and $\mathrm{PbCl}^{2+}$. The peaks appeared at $1577 \mathrm{~cm}^{-1}$ to $1590 \mathrm{~cm}^{-1}$ of N-H bend, the peaks $1413 \mathrm{~cm}^{-1}, 1465$ $\mathrm{cm}^{-1}$ of $\mathrm{C}=\mathrm{C}$ stretch, the peaks $1016 \mathrm{~cm}^{-1}$ and $1020 \mathrm{~cm}^{-1}$ of $\mathrm{C}-\mathrm{O}$ stretch are 
observed for $\mathrm{MAPbI}_{3}$. The peak at $945 \mathrm{~cm}^{-1}$ is shifted to $950 \mathrm{~cm}^{-1}$ of $=\mathrm{C}-\mathrm{H}$ bending and are assigned to the stretching mode of $\mathrm{NH}^{3+} / \mathrm{CH}_{3}$ ions rocking in $\mathrm{CH}_{3} \mathrm{NH}_{3} \mathrm{PbI}_{3-\mathrm{X}} \mathrm{Cl}_{\mathrm{X}}$ and $\mathrm{CH}_{3} \mathrm{NH}_{3} \mathrm{PbI}_{3}$. For $\mathrm{MAPbI}_{3-\mathrm{X}} \mathrm{Cl}_{\mathrm{X}}$ the peak at $711 \mathrm{~cm}^{-1}$ of C$\mathrm{Cl}$ stretch wasrecorded. The differences in the assigned vibrational modes result from $\mathrm{PbCl}_{2}$ and $\mathrm{PbI}_{2}$.

The shifts in the vibrations and the change in the functional groups peaks broadening observed in the spectra are attributed to the formation of the two different perovskites. High transmittance at a frequency means there are few bonds to absorb that "color" or light in the sample, low transmittance means there is a high population of bonds which have vibrational energies corresponding to the incident light [45-47].
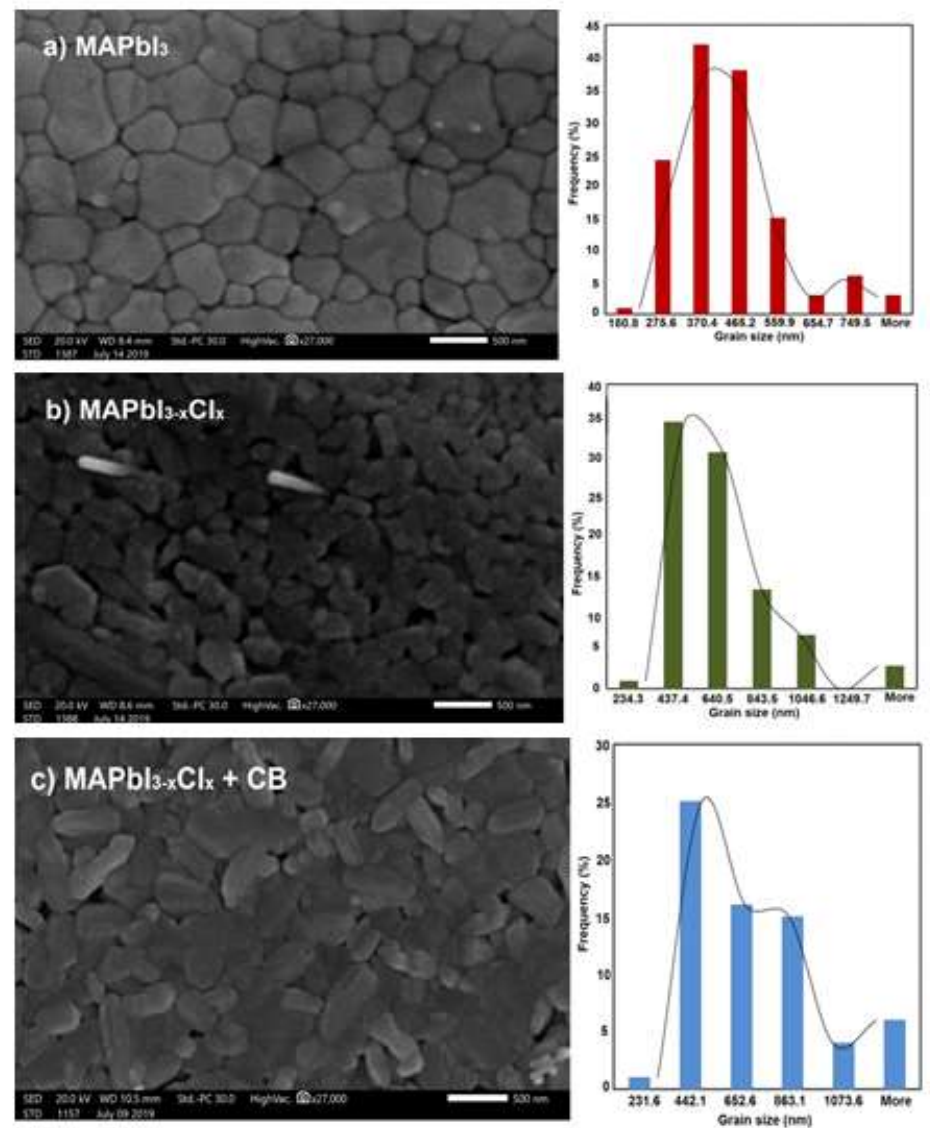

Fig. (7): $\mathrm{SEM}$ images of (a) $\mathrm{MAPbI}_{3}$ (b) $\mathrm{MAPbI}_{3-\mathrm{x}} \mathrm{Cl}_{\mathrm{x}}$ and (c) $\mathrm{MAPbI}_{3-\mathrm{x}} \mathrm{Cl}_{\mathrm{x}}+\mathrm{CB}$ thin film.

The morphological changes in the $\mathrm{MAPbI}_{3}, \mathrm{MAPbI}_{3-\mathrm{x}} \mathrm{Cl}_{\mathrm{x}}$ and $\mathrm{MAPbI}_{3-\mathrm{x}} \mathrm{Cl}_{\mathrm{x}}$ with $\mathrm{CB}$ treatment perovskite films by using SEM were inspected as shown in Fig. (7 a, b, c), respectively, and The statistical histogram of grain size of perovskite thin films is demonstrated. It is noticed that the large variations in 
crystallite size with islands of sub-micron size can be seen clearly all over the surface. The presence of the random structures, grain boundaries and pinholes on the surface increases the possibility of current leakage.

The surface of $\mathrm{MAPbI}_{3}$ is uniform but there are pinholes, a lot of grain boundaries and the average of grain size is nearly $391.8 \mathrm{~nm}$ as shown in Fig. (7.a), but in Fig. (7.b) the new composited $\mathrm{MAPbI}_{3-\mathrm{x}} \mathrm{Cl}_{\mathrm{x}}$ PSC films produces less grain boundaries and the average of grain size is $537.4 \mathrm{~nm}$, The Cl-doped perovskite films show improved crystalline structure and morphology anddecrease the grain boundaries. Comparing $\mathrm{MAPbI}_{3-\mathrm{x}} \mathrm{Cl}_{\mathrm{x}}$ with the non-polar solvent treatment, the PSC film without any treatment process showed bad surface coverage, but for the cases of the CB treatment Fig. 7.b shows good coverage and no pinholes. On the other hand, relatively irregular distribution in grain sizes was modulated to be regularly distributed crystallites, and much planar surface and larger grain sizes were observed that in average grain size $609.5 \mathrm{~nm}$ indicating the best crystalline quality for device performance. Larger grains reduce the recombination

probability of electron-hole pairs at the grain boundaries and defect points, leading to the improvement in transporting rate of photo generated carrier and high-performance device [27, 48, and 49].To make sure that the charge does not recombine again throughout the cell, and to obtain the greatest cell performance we will go to the interface passivation method that depends on the electron transport layer $\left(\mathrm{MP}-\mathrm{TiO}_{2}\right)$ to improve its surface properties, SEM images of the pristine and treated $\left(\mathrm{MP}-\mathrm{TiO}_{2}\right)$ showed that a very thin layer of compact titanium covered the surface of $\mathrm{TiO}_{2}$ nanoparticles and improved its morphology and decreased the pin holes as shown in Fig. ( $8 \mathrm{a}$ and8b) and that agree with literature [50].
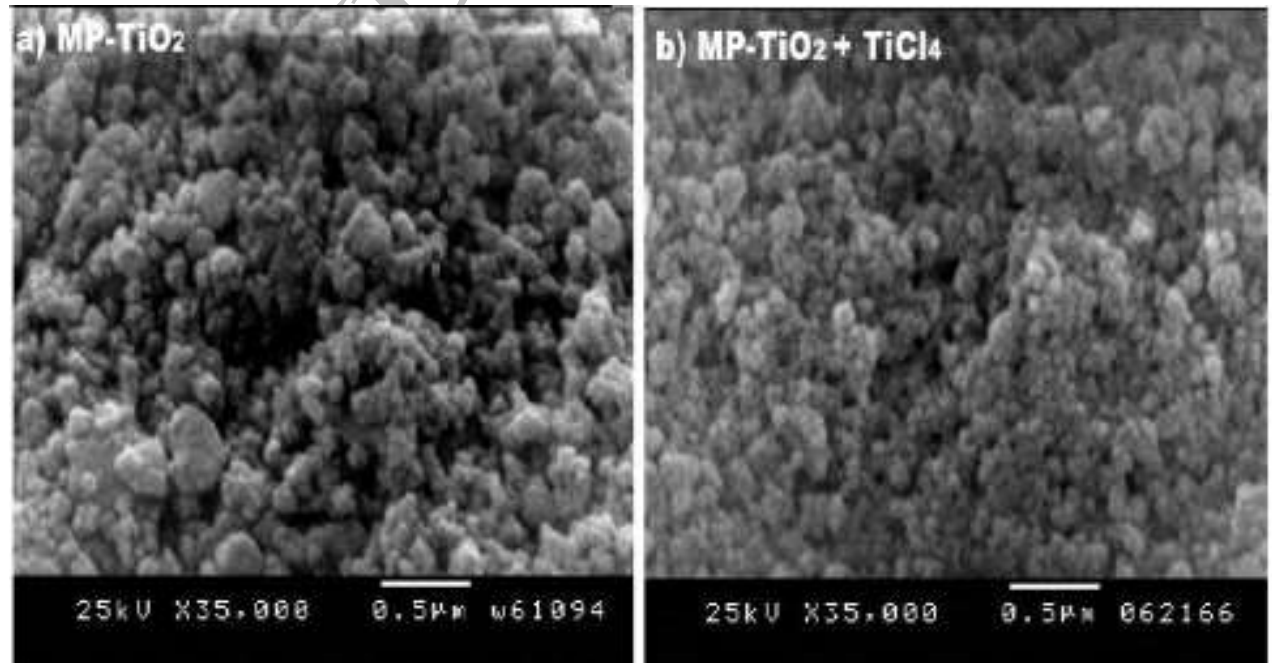

Fig. (8): SEM images of (a)MP-TiO 2 , (b)MP-TiO ${ }_{2}+\mathrm{TiCl}_{4}$ thin film. 


\subsection{Effect of the passivation methods on the performance of PSCs}

Although comparable PCEs are achieved in Figure (9), the reproducibility of the $\mathrm{MAPbI}_{3}$ devices is poorer than that of the Cl-doped $\mathrm{MAPbI}_{3-\mathrm{x}} \mathrm{Cl}_{\mathrm{x}}$ devices. To explore the benefits of the $\mathrm{PbCl}_{2}$ additive to the perovskite precursor on the performance of solar cells, solar cells based on different structures from $\mathrm{PbI}$ and the other cell $10 \% \mathrm{PbCl}_{2}$ contents are fabricated and the parameters of $\mathrm{J}_{\mathrm{sc}}, \mathrm{V}_{\mathrm{oc}}, \mathrm{FF}$ and PCE are summarized in Table (1). PSCs based on FTO/BL/MP-TiO${ }_{2} / \mathrm{MAPbI}_{3} / \mathrm{C}$ compared with $\mathrm{FTO} / \mathrm{BL}-\mathrm{TiO}_{2} / \mathrm{MP}-\mathrm{TiO}_{2} / \mathrm{MAPbI}_{3-\mathrm{x}} \mathrm{Cl}_{\mathrm{x}} / \mathrm{CCE}$ (surface passivation) indicate that both cells have a single absorber layer of $\mathrm{MAPbI}_{3}$ or $\mathrm{MAPbI}_{3-\mathrm{x}} \mathrm{Cl}_{\mathrm{x}}$. However, $\mathrm{FTO} / \mathrm{BL}-\mathrm{TiO}_{2} / \mathrm{MP}-\mathrm{TiO}_{2} / \mathrm{MAPbI}_{3-\mathrm{x}} \mathrm{Cl}_{\mathrm{x}} / \mathrm{CCE}$ exhibits an improvement in the power conversion efficiency PCE by $40 \%$ and raises the $\mathrm{J}_{\mathrm{sc}}$ by $90 \%$ as compared to $\mathrm{FTO} / \mathrm{BL} / \mathrm{MP}-\mathrm{TiO}_{2} / \mathrm{MAPbI}_{3} / \mathrm{C}$, due to the substitution of $\mathrm{PbI}_{2}$ by $\mathrm{PbCl}_{2}$ in the precursor solution of $\mathrm{MAPbI}_{3}$. The substitution improves the $J_{\text {sc }}$ due to the high charge carrier transport properties of $\mathrm{MAPbI}_{3-\mathrm{x}} \mathrm{Cl}_{\mathrm{x}}$ as indicated by PL. Where the higher mobility and more efficient transportation ability in the PSCs are responsible for the higher $\mathrm{J}_{\mathrm{sc}}$ of PSCs $[51,52]$. These observations imply that a better contact and charge transfer through cells with self-passivation method. The voids at the grain boundary increase the recombination process in the solar cell due to poor contact between the light absorbing particles. To overcome these defects, we add a new passivation material into the cell, which is an antisolvent solution from cholorobenzen.

Comparing $\mathrm{FTO} / \mathrm{BL} / \mathrm{MP}-\mathrm{TiO}_{2} / \mathrm{MAPbI}_{3} / \mathrm{C}$ with $\mathrm{FTO} / \mathrm{BL}-\mathrm{TiO}_{2} / \mathrm{MP}-\mathrm{TiO}_{2} /$ $\mathrm{MAPbI}_{3-\mathrm{x}} \mathrm{Cl}_{\mathrm{x}} / \mathrm{CCE}$, it is observed that the performance of $\mathrm{FTO} / \mathrm{BL}-\mathrm{TiO}_{2} / \mathrm{MP}-$ $\mathrm{TiO}_{2} / \mathrm{MAPbI}_{3-\mathrm{x}} \mathrm{Cl}_{\mathrm{x}} / \mathrm{CB} / \mathrm{CCE}$ (surface passivation) is better than that of $\mathrm{FTO} / \mathrm{BL}-$ $\mathrm{TiO}_{2} / \mathrm{MP}-\mathrm{TiO}_{2} / \mathrm{MAPbI} \mathrm{H}_{3-\mathrm{x}} \mathrm{Cl}_{x} / \mathrm{CCE}$ due to the improvement of the surface wetting properties of perovskite film after adding $\mathrm{CB}$ treatment the enhancement in the optical and morphological properties as proved by the absorption and SEM images in Figure (3) and (7). The typical $\mathrm{MAPbI}_{3-\mathrm{x}} \mathrm{Cl}_{\mathrm{x}}$ with the antisolvent treatment cell has PCEs of $4.46 \%$ and higher in Jsc, Voc and FF.

Table. (1): Jsc, Voc, FF, and PCE of the cells without and with different passivation.

\begin{tabular}{|l|c|c|c|c|}
\hline \multicolumn{1}{|c|}{ PSCs } & $\begin{array}{c}\text { Jsc } \\
(\mathrm{mA} / \mathrm{cm} 2)\end{array}$ & $\begin{array}{c}\text { Voc } \\
(\mathrm{V})\end{array}$ & FF & $\begin{array}{c}\text { PCE } \\
\%\end{array}$ \\
\hline FTO/BL/MP-TiO2/MAPbI3/C & 16.8 & 0.227 & 0.215 & 1.64 \\
\hline FTO/BL-TiO2/MP-TiO2/MAPbI3-xClx/CCE & 18.52 & 0.434 & 0.255 & 4.1 \\
\hline $\begin{array}{l}\text { FTO/BL-TiO2/Mp-TiO2/MAPbI3- } \\
\text { xClx/CB/CCE }\end{array}$ & 19.66 & 0.436 & 0.26 & 4.46 \\
\hline $\begin{array}{l}\mathrm{FTO} / \mathrm{BL}-\mathrm{TiO} / \mathrm{MP}-\mathrm{TiO} 2 / \mathrm{TiCl} / \mathrm{MAPbI3}- \\
\mathrm{xClx} / \mathrm{CB} / \mathrm{CCE}\end{array}$ & 20 & 0.56 & 0.29 & 6.5 \\
\hline
\end{tabular}




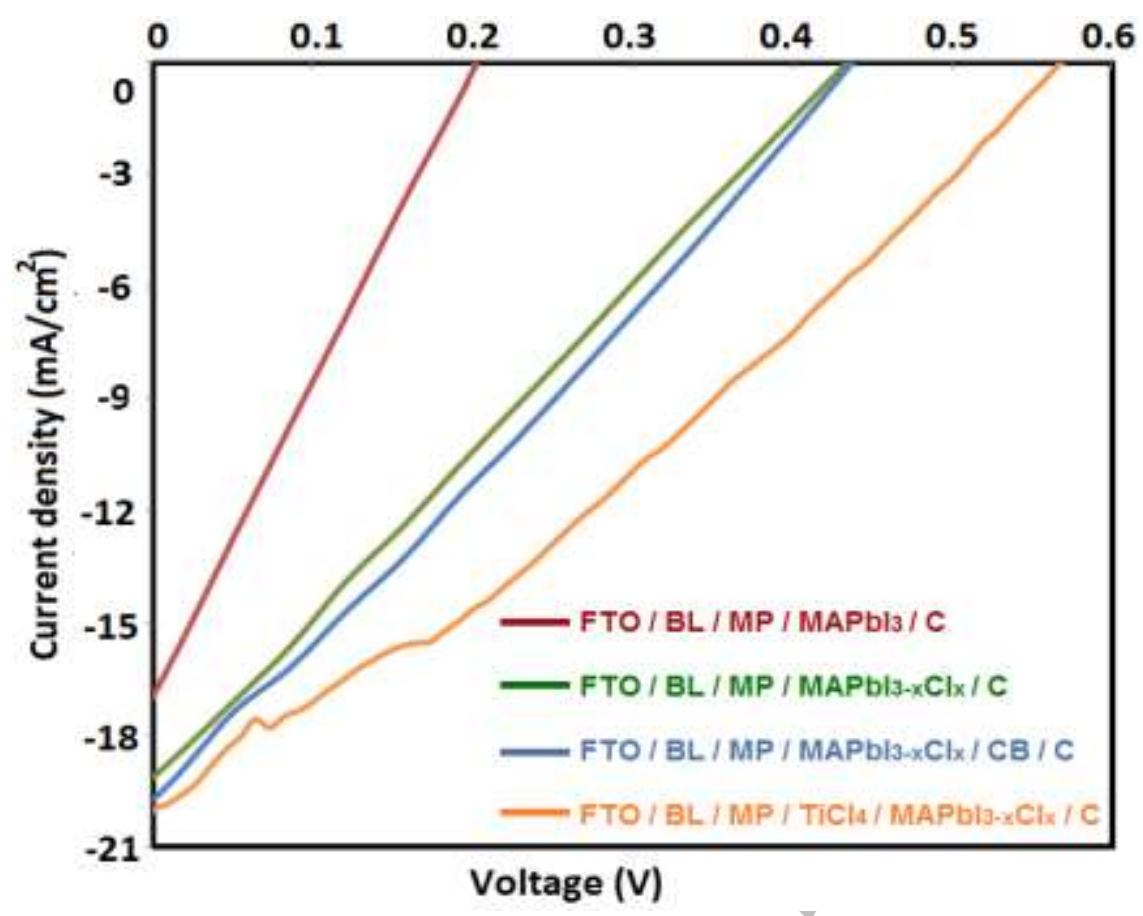

Fig. (9): J-V curves of the fabricated cells without out passivation media and the other with self, surface and interface passivation.

It is noted that FF of the PSCs has a low value $(0.25-0.26)$ due to the high series resistance (Rs) between the perovskite $/ \mathrm{TiO}_{2}$ and perovskite/carbon interfaces. The reduction in Voc of FTO/BL/MP-TiO $/ \mathrm{MAPbI}_{3} / \mathrm{C}$ and $\mathrm{FTO} / \mathrm{BL}-$ $\mathrm{TiO}_{2} / \mathrm{MP}-\mathrm{TiO}_{2} / \mathrm{MAPbI}_{3-\mathrm{x}} \mathrm{Cl}_{\mathrm{x}} / \mathrm{CCE}$ might be attributed to a reduction in the shunt resistance of the solar cell [56]. Moreover, there is another additional fabricated architecture consisted of FTO/BL-TiO $/ \mathrm{MP}_{2} \mathrm{TiO}_{2} / \mathrm{TiCl}_{4} / \mathrm{MAPbI}_{3-\mathrm{x}} \mathrm{Cl}_{\mathrm{x}} / \mathrm{CCE}$. By comparing its performance with cell-3 (surface passivation), it is exhibited the highest values in $\mathrm{J}_{\mathrm{sc}}, \mathrm{V}_{\mathrm{oc}}, \mathrm{FF}$ and the PCE as compared to the other cells. $\mathrm{TheFTO} / \mathrm{BL}-\mathrm{TiO}_{2} / \mathrm{MP}-\mathrm{TiO}_{2} / \mathrm{MAPbI}_{3-\mathrm{x}} \mathrm{Cl}_{\mathrm{x}} / \mathrm{CB} / \mathrm{CCE}$ cell has the highest $\mathrm{J}_{\mathrm{sc}}$ of 20 $\mathrm{mA} / \mathrm{cm}^{2}$, FF of 0.29 , and $\mathrm{V}_{\text {oc }}$ of $0.56 \mathrm{~V}$ and PCE of $6.5 \%$.

\section{Conclusion}

This work indicated that different passivation techniques affected and improved the performance of the fabricated PSCs. The $\mathrm{MAPbI}_{3-\mathrm{x}} \mathrm{Cl}_{\mathrm{x}}$ film without CB treatment had a lower PL peak intensity, indicating the lower excitation and higher recombination rate than the $\mathrm{MAPbI}_{3-\mathrm{x}} \mathrm{Cl}_{\mathrm{x}}$ thin layer treated by CB.It was found that the maximum performance is of the fabricated and passivated PSCs with a structure of $\left(\mathrm{FTO} / \mathrm{BL} / \mathrm{MP}-\mathrm{TiO}_{2} / \mathrm{TiCl}_{4} / \mathrm{MAPbI}_{3-\mathrm{x}} \mathrm{Cl}_{\mathrm{x}} / \mathrm{CB} / \mathrm{CCE}\right)$ where it has $\mathrm{J}_{\mathrm{sc}}, \mathrm{V}_{\mathrm{oc}}, \mathrm{FF}$ and efficiency of $20 \mathrm{~mA} / \mathrm{cm}^{2}, 0.56 \mathrm{~V}, 0.29$ and $6.5 \%$, respectively. 


\section{Data Availability}

The data that support the findings of this study are available from the corresponding author upon reasonable request.

\section{Conflict of interest}

The authors declare that there are no conflicts of interest.

\section{References}

1. Zhaoyi Wan, Journal of Metals Research,35 (16), 2166-2189, (2020)

2. Jeon, N.J.; Noh, J.H.; Yang,W.S.; Kim, Y.C.; Ryu, S.; Seo, J.; Seok, S.I. Nature, 517, 476-480, (2015).

3. Park, N.G. Perovskite solar cells: An emerging photovoltaic technology. Materials Today, 18, 65-72.:(2014).

4. Green, M.A.; Baillie, A.H.; Snaith, H.J. The emergence of perovskite solar cells. Nature Photonics, 8, 506-514. (2014).

5. Qiliang Chen, Lianjie Zhang, Shaker Ebrahim, MoatazSoliman, Cheng Zhang, and QiquanQiao, Polymer 54, 223-229, (2013).

6. A.H. Ip, L.N. Quan, M.M. Adachi, J.J. McDowell, J.X. Xu, D.H. Kim, E.H. Sargent, Applied Physics Letters, 106, 143902, (2015)

7. Y.W. Li, Y. Zhao, Q. Chen, Y. Yang, Y.S. Liu, Z.R. Hong, Z.H. Liu, Y.T. Hsieh, L.Meng, Y.F. Li, Y. Yang, Journal of the American Chemical Society,137, 15540-15547, (2015).

8. J.X. Song, E.Q. Zheng, J. Bian, X.F. Wang, W.J. Tian, Y. Sanehira, T. Miyasaka, Journal of Materials Chemistry A, 3, 10837-10844, (2015).

9. N. Arora, M.I. Dar, M. Abdi-Jalebi, F. Giordano, N. Pellet, G. Jacopin, R.H. Friend, S.M. Zakeeruddin, M. Grazel. Nano Letters, 16, 7155-7162, (2016).

10. W.J. Ke, C.X. Xiao, C.L. Wang, B. Saparov, H.S. Duan, D.W. Zhao, Z.W. Xiao, P. Schulz, S.P. Harvey, W.Q. Liao, W.W. Meng, Y. Yu, A.J. Cimaroli, C.S. Jiang, K. Zhu, M. Al-Jassim, G.J. Fang, D.B. Mitzi, Y.F, Advanced Materials, 28, 5214-5221, (2016).

11. P. Zhao, B. J Kim, H. S. Jung, Materials Today Energy, 7, 267-286, (2018).

12. L. Etgar, P. Gao , Z. Xue , Q. Peng, A. K. Chandiran , B. Liu , M. K. Nazeeruddin , M. Grätzel, Journal of American Chemical Society, 134, 17396-17399. (2012).

13. A. Mei , X. Li , L. Liu , Z. Ku , T. Liu , Y. Rong, M. Xu , M. Hu , J. Chen, Y. Yang, M. Grätzel, H. Han, Science, 345, 295-298, (2014).

14. Hao Li, Dandan Yang, Ting Zhang, Peng Zhang, Feng Wang, Chaojie Qin, Ruihan Yang, Zhi David Chen, Shibin Li, Journal of Materials Science, 54, 11556-11563, (2019).

15. P. D. Matthews, D. J. Lewis, P. O'Brien, Journal of Materials Chemistry A, 5, 17135-17150, (2017). 
16. M. L. Petrus, J. Schlipf, C. Li, T. P. Gujar, N. Giesbrecht, P. Müller-Buschbaum, M. Thelakkat, T. Bein, S. Hüttner, P. Docampo. Advanced Energy Materials, 7, 1700264, (2017).

17. Mustafa Aboulsaad, Ayman El Tahan, Moataz Soliman, Said El-Sheikh, Shaker Ebrahim, Journal of Materials Science: Materials in Electronics, 30:19792-19803, (2019).

18. M. Abdi-Jalebi, M.I. Dar, A. Sadhanala, S.P. Senanayak, M.Gratzel, R.H. Friend, Journal of Visualized Experiments, 121, 55307, (2017).

19. Fan, H., Yang, Z., Ren, X., Yin, M., Gao, F., \& Liu, AIP Advances, 6, 015314, (2016).

20. More, V., Shivade, V., \&Bhargava, P. Transactions of the Indian Ceramic Society, 75, 59-62, (2016).

21. Ito, S., Murakami, T. N., Comte, P., Liska, P., Grätzel, C., Nazeeruddin, M. K., \&Grätzel, M. Thin solid films, 516, 4613-4619, (2008).

22. Wang, X., Fang, Y., He, L., Wang, Q., \& Wu, T. Materials Science in Semiconductor Processing, 27, 569-576, (2014).

23. Xiao, Z., Bi, C., Shao, Y., Dong, Q., Wang, Q., Yuan, Y.,...\& Huang, J. Energy \& Environmental Science, 7, 2619-2623, (2014).

24. Duan, B., Ren, Y., Xu, Y., Chen, W., Ye, Q., Huang, Y. \& Dai, S. Inorganic Chemistry Frontiers, 4, 473-480, (2017).

25. M. Habib, M. Feteha, M. Soliman, A. Abdel Motagaly, S. El-Sheikh, andSh. Ebrahim, Journal of Materials Science: Materials in Electronics, 31 , 18870 18882, ( 2020 )

26. Ren, Y. K., Ding, X. H., Wu, Y. H., Zhu, J., Hayat, T., Alsaedi, A. \& Dai, S. Y. Journal of Materials Chemistry A, 5, 20327-20333, (2017).

27. N.D. Pham, V.T. Tiong, P. Chen, L. Wang, G.J. Wilson, J. Bell, H. Wang, Journal of Materials Chemistry A, ,5, 5195-5203, (2017).

28. Zhang, L., Liu, T., Liu, L., Hu, M., Yang, Y., Mei, A., \& Han, H. Journal of Materials Chemistry A, 3, 9165-9170, (2015).

29. Zhao, P., Han, M., Yin, W., Zhao, X., Kim, S. G., Yan, Y. Jung, H. S. ACS applied materials \& interfaces, 10, 10132-10140, (2018).

30. Ban-Suk Park, Seojun Lee, Saemon Yoon, Tae-Jun Ha, Dong-Won Kang, Applied Surface Science, 427, 421-426, (2017).

31. Zhang, H., Shi, Y., Yan, F., Wang, L., Wang, K., Xing, Y., ...\& Ma, T. Chemical Communications, 50, 5020-5022, (2014).

32. Roose, B., Gödel, K. C., Pathak, S., Sadhanala, A., Baena, J. P. C., Wilts, B. D. \& Abate, A. Advanced Energy Materials, 6, 1501868, (2016).

33. W. Li, S. Shah, C. P. Huang, O. Jung, and C. Ni. Materials Science and Engineering B, 96, 247-253, (2002).

34. X. W. Zhang, M. H. Zhou, and L. C. Lei. Catalysis Communications, 7, 427431, (2006).

35. Timothy H. Gfroerer, Encyclopedia of Analytical Chemistry: Applications, Theory and Instrumentation 9209-9231, (2006). 
36. N. Sakai, S. Pathak, H.-W. Chen, A.A. Haghighirad, S.D. Stranks, T. Miyasaka, H.J. Snaith, Journal of Materials Chemistry A, 4, 4464-4471, (2016).

37. Tarek M. Abdel-Fattah, Shaker Ebrahim, MoatazSoliman, and Mostafa Hafez, ECS Journal of Solid State Science and Technology, 2 (6) M13-M16 (2013).

38. K.-F. Lin, S.H. Chang, K.-H. Wang, H.-M. Cheng, K.Y. Chiu, K.-M. Lee, S.H. Chen, C.-G. Wu, Solar Energy Materials and Solar Cells, 141, 309-314, (2015).

39. Yu H, Wang F, Xie F, Li W, Chen J, Zhao N, Advanced Functional Materials, 24, 7102-7108, (2015),

40. Bi D, Tress W, Dar MI et al. Science Advances, 2, e1501170-e1501170, (2016).

41. C. Huang, N. Fu, F. Liu, L. Jiang, X. Hao, H. Huang, Solar Energy Materials and Solar Cells, 145, 231-237, (2016).

42. Guo, X., McCleese, C., Kolodziej, C., Samia, A. C., Zhao, Y., \&Burda, C, Dalton Transactions, 45, 3806-3813, (2016)

43.

Joumal of Materials Chemistry A, 3, 20849 20862, (2015),

44. Abdelmagid, A., El Tahan, A., Habib, M., Anas, M., Soliman, M., Synthetic Metals, 259, 116232, (2020).

45. Cho, K. T., Paek, S., Grancini, G., Roldán-Carmona, C., Gao, P., Lee, Y., \&Nazeeruddin, M. K, Energy \& Environmental Science, 10, 621-627, (2017)

46. Liu, D., Liu, C., Wu, L., Li, W., Chen, F., Xiao, B. \&Feng, L. RSC Advances, 6, 51279-51285, (2016).

47. XinGuo, Christopher McCleese, Charles Kolodziej, Anna C. S. Samia, Yixin Zhao, Clemens Burda, Dalton Transactions, 45, 38063813, (2016).

48. Song, Z., Watthage, S. C., Phillips, A. B., Tompkins, B. L., Ellingson, R. J., \&Heben, M. J, Chemistry of Materials, 27, 4612-4619, (2015).

49. Li, Z., Kolodziej, C., McCleese, C., Wang, L., Kovalsky, A., Samia, A. C., \&Burda, C, Nanoscale Advances, 1, 827-833, (2019).

50. MojtabaAbdi-Jalebi, M. Ibrahim Dar, AdityaSadhanala, Satyaprasad P. Senanayak, Fabrizio Giordano, Shaik Mohammed Zakeeruddin, Michael Grätzel, Richard H. Friend, J. Phys. Chem. Lett., 7, 16, 3264-3269, (2016)

51. Unger EL, Hoke ET, Bailie CD, Nguyen WH, Bowring AR, Heumuller T, Christoforod MG, McGehee MD. Energy \& Environmental Science, 7, 3690-3698, (2014).

52. Wehrenfennig, C., Eperon, G. E., Johnston, M. B., Snaith, H. J., \&Herz, L. M., Advanced materials, 26, 1584-1589, (2014). 